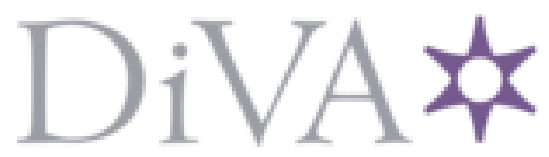

http://www.diva-portal.org

\title{
Postprint
}

This is the accepted version of a paper published in European Criminal Law Review. This paper has been peer-reviewed but does not include the final publisher proof-corrections or journal pagination.

Citation for the original published paper (version of record):

Jacob, Ö. (2015)

Subsidiarity and EU Procedural Criminal Law.

European Criminal Law Review, 5(1): 19-45

http://dx.doi.org/10.5771/2193-5505-2015-1-19

Access to the published version may require subscription.

N.B. When citing this work, cite the original published paper.

Permanent link to this version:

http://urn.kb.se/resolve?urn=urn:nbn:se:oru:diva-43747 


\section{SUBSIDIARITY AND EU PROCEDURAL CRIMINAL LAW}

\section{by Jacob Öberg ${ }^{\mathrm{i}}$}

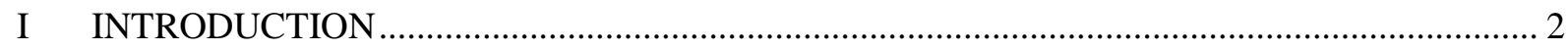

II WHAT ARE THE LEGITIMATE JUSTIFICATIONS FOR HARMONIZATION OF EU

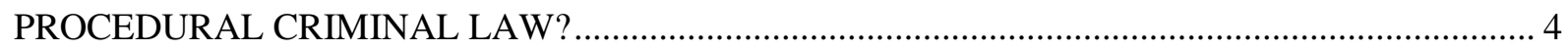

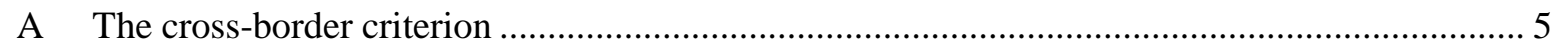

B) Improvement of judicial cooperation and mutual recognition ............................................ 12

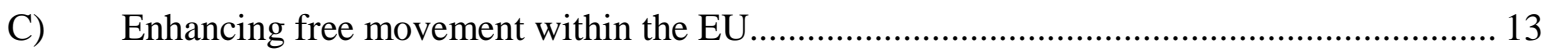

D Limits to the justifications for harmonization of EU procedural criminal law......................... 15

III A CONCRETE SUBSIDIARITY ASSESSMENT OF THE VICTIMS DIRECTIVE............. 18

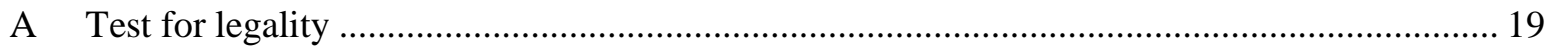

B Is there adequate reasoning in the Victims Proposal to justify compliance with the subsidiarity

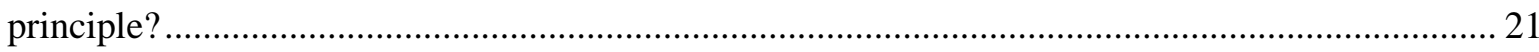

C Is there relevant evidence in the Victims Proposal to justify compliance with subsidiarity? ... 24

IV CONCLUSIONS AND REFLECTIONS 27 
Subsidiarity is a well-known concept in EU law and EU legal scholarship. ${ }^{1}$ It requires the EU legislator to show that, because of the scale or implications of the measure, EU action is more effective than Member State action to achieve a specific EU objective. ${ }^{2}$

This being so, we must consider whether it makes sense to talk about subsidiarity when contemplating EU harmonization in the field of national procedural criminal law; I sustain that subsidiarity offers an intriguing approach to EU procedural criminal law as it forces us to ask what the rationales behind harmonization in this field are. ${ }^{3}$ The Manifesto on EU Procedural Criminal $\mathrm{Law}^{4}$ offers an appropriate framework for analysing subsidiarity in this regard. The Manifesto takes a critical approach to EU criminal law harmonization and suggests several principles limiting the EU legislator when adopting criminal law legislation. What is commendable with the Manifesto's approach is that they really try to show, by analysing specific pieces of EU legislation, how the different principles should be enforced. In order to properly implement the subsidiarity principle, the Manifesto employ a procedural approach to subsidiarity which seems well in tune with the new subsidiarity protocol attached

\footnotetext{
${ }^{1}$ See e.g. George Bermann ‘Taking Subsidiarity Seriously' (1994) 94 Columbia Law Review 332; Koen Lenaerts 'The Principle of Subsidiarity and the Environment in the European Union: Keeping the Balance of Federalism' (1994) 17 Fordham International Law Journal 846; Edward T Swaine, 'Subsidiarity and SelfInterest: Federalism at the European Court of Justice' (2000) 41 Harvard International Law Journal; Mattias Kumm, 'Constitutionalizing Subsidiarity in Integrated Markets: The Case of Tobacco Regulation in the European Union' 12 (2006) European Law Journal 503; Thomas Horsley 'Subsidiarity and the Court of Justice: Missing Pieces in the Subsidiarity Jigsaw?' (2012) 50 Journal of Common Market Studies 267.

${ }^{2}$ Observe the 'elusiveness' of the term 'effective' which can probably mean both more efficient or more appropriate in political terms, e.g. better in protecting national autonomy. Article 5(3) in the TEU suggests that'... the Union shall act only if and in so far as the objectives of the proposed action cannot be sufficiently achieved by the Member States.........but can rather, by reason of the scale or effects of the proposed action, be better achieved at Union level.' I have underlined the words 'scale or effects' and 'better achieved' to suggest that there may be a mix between efficiency considerations and other non-economic considerations as fairness, diversity, democracy and justice in deciding on the right for the EU to act. As argued below, I do, however, believe that subsidiarity should be more a question of efficiency than 'appropriateness'. It is easier to substantiate the subsidiarity principle with hard legal criteria and measure whether EU legislation conforms to the subsidiarity principle if we see it in economic terms. See, however, Bermann (n 1) 334, 389; Kumm (n1), 515,518 , which seem to take a broader approach to subsidiarity.

${ }^{3}$ See Jörg Monar, 'The development of the European Union's criminal justice system and its judicial rights deficit', (2006) 21 L'Europe des Libertés. <http://leuropedeslibertes.ustrasbg.fr/rubrique.php?id_rubrique=40>Accessed 22 August 2014.

${ }^{4}$ See Petter Asp and others, 'A Manifesto on European Criminal Policy', (2013) 11 Zeitschrift für Internationale Strafrechtsdogmatik 430 .
} 
to the Lisbon Treaty. ${ }^{5}$ According to the Manifesto, subsidiarity must be thoroughly justified in accordance with Protocol no 2 and applied separately in relation to every instrument and each part of that instrument. The proposition of an EU procedural criminal law measure must always be preceded by an extensive evaluation that weighs all circumstances, takes into account all alternative courses of action and presents serious substantive arguments to defend compliance with the subsidiarity principle. This justification-based and procedural approach to subsidiarity is to be welcomed and I therefore intend to adopt this approach throughout the analysis in this article. ${ }^{6}$

Having briefly accounted for the link to the Manifesto, I will explain the scope of the examination. This article analyses the EU's competence to harmonize domestic criminal procedural laws ${ }^{7}$ as enshrined in Article 82(2) TFEU:

'...To the extent necessary to facilitate mutual recognition of judgments and judicial decisions and police and judicial cooperation in criminal matters having a cross-border dimension, the European Parliament and the Council may, ... establish minimum rules. Such rules shall take into account the differences between the legal traditions and systems of the Member States. They shall concern:

(a) mutual admissibility of evidence between Member States;

(b) the rights of individuals in criminal procedure;

(c) the rights of victims of crime...'

It could be queried why subsidiarity should be examined when analysing legislation adopted under Article 82 (2) TFEU. First, it is clear that subsidiarity applies to all EU legislation where the competence for the EU is not exclusive. ${ }^{8}$ In addition, I believe that subsidiarity permeates the whole design of Article 82(2) TFEU since the exercise of the competence is conditioned upon the fact that the proposed legislative measures 'facilitate mutual recognition' in criminal matters having a 'cross-border dimension'. The real issue in relation to harmonization of EU procedural criminal law is, therefore, whether cooperation should be

\footnotetext{
${ }^{5}$ See Protocol (No 2) On the Application of the Principles of Subsidiarity and Proportionality OJ [2010] C 83/206.

${ }^{6}$ Manifesto (n 4) 432-433.

${ }^{7}$ Fletcher, Gilmore and Lööf, however, employ the concept of 'forensic criminal procedure' instead of 'national criminal procedural rules' to define the rules involved; see Maria Fletcher, Bill Gilmore and Robin Lööf, $E U$ Criminal Law and Justice (Edward Elgar 2008) 138.

${ }^{8}$ See Article 5(3) TEU.
} 
limited to 'cross-border' cases. Since the EU must always, pursuant to the subsidiarity criterion, show that the issue to be regulated is of a transnational nature ${ }^{9}$, it seems that the 'cross-border dimension' criterion in Article 82(2) TFEU is superfluous. Given this, we must focus on the 'cross-border' criterion inherent in the subsidiarity principle as a limit to the exercise of EU competence under Article 82(2) TFEU.

The first section of the article examines the legitimate justification for EU action in the field of EU criminal procedure and the limits to their use. It argues for a narrow understanding of subsidiarity, suggesting that EU procedural criminal law legislation can only be directed at problems which are of a cross-border nature and cannot be dealt with by Member States. The second section analyses the legality of the Victims Directive ${ }^{10}$ on the basis of the subsidiarity principle. It sustains that the proposed Victims Directive can be criticised on subsidiarity grounds as the directive fails to adequately account for the link between victim rights and the application of the principle of mutual recognition and since the directive fails to explain properly the need to regulate local victim rights. The third part finally summarizes the findings and draws some broader reflections on the basis of the examination. It is argued that EU initiatives in procedural criminal law have not primarily been driven by the need to facilitate mutual recognition and free movement but rather motivated by a general concern to deliver a common European sense of justice.

\section{WHAT ARE THE LEGITIMATE JUSTIFICATIONS FOR HARMONIZATION OF EU PROCEDURAL CRIMINAL LAW?}

This section accounts for three legitimate justifications for EU action under the subsidiarity principle; the cross-border argument, the mutual recognition justification and the free movement rationale, and their use for harmonization of national procedural criminal laws.

If subsidiarity is to act as a check on the EU legislator when envisaging harmonization of national procedural criminal law, there must be some objective standard against which subsidiarity can be assessed. In this regard, it is pertinent to review the Edinburgh guidelines ${ }^{11}$

\footnotetext{
${ }^{9}$ See below section II (A).

${ }^{10}$ See Directive 2012/29/EU of the European Parliament and of the Council of 25 October 2012 establishing minimum standards on the rights, support and protection of victims of crime, and replacing Council Framework Decision 2001/220/JHA [2012] OJ L 315/57 ('Victims Directive' 'Directive').

${ }^{11}$ European Council, 'Conclusions adopted at Edinburgh European Council, Annex 1 to Part A: Overall Approach to the Application by the Council of the Subsidiarity Principle and Article $3 \mathrm{~b}$ of the Treaty on European Union', Bulletin of the European Communities 12-1992, 11-12 December 1992.
} 
which provide the most detailed substantive criteria as to how subsidiarity should be conceptualised. ${ }^{12}$ These guidelines list three criteria; the cross-border criterion, the 'Treaty requirement' criterion and the 'clear benefits' criterion that must be taken into account in assessing the need for Union action. ${ }^{13}$ I will start by considering the cross-border criterion since this is the primary rationale for Union action in the guidelines.

\section{The cross-border criterion}

The cross-border criterion is one of the core justifications for Union harmonization under the Treaties. ${ }^{14}$ The clearest cases in which the scale or effects of a certain problem require Union action are those involving 'transnational' elements. ${ }^{15}$ The scope of Union competences both in the field of legislative action ${ }^{16}$ and the application of the free movement rules ${ }^{17}$ have normally, at least before the ratification of the Lisbon Treaty and the Court's recent rulings on EU citizenship ${ }^{18}$, depended on the need to show a cross-border aspect. EU action is justified where a problem affects more than one Member State at the same time and de-centralized decision-making by independent states cannot adequately promote the welfare of citizens

\footnotetext{
${ }^{12}$ The Court of Justice of the European Union ('Court', 'Court of Justice') assumes that the Edinburgh guidelines (n 11), as they were previously codified by the Amsterdam Protocol (no 30) on the application of the principles of subsidiarity and proportionality [1997] OJ C 321/308, provide for an authoritative definition of subsidiarity; see Case C-491/01 British American Tobacco (Investments) and Imperial Tobacco [2002] ECR I11453, para 178; CaseC-58/08 Vodafone and Others [2010] ECR I-04999, paras 72-74.

${ }^{13}$ The Edinburgh guidelines, (n 11) 20, state that the Union should consider the following criteria to decide whether there is a need for EU action:

'- the issue under consideration has transnational aspects which cannot be satisfactorily regulated by action by Member States; and/or

- actions by Member States alone or lack of Community action would conflict with the requirements of the Treaty (such as the need to correct distortion of competition or avoid disguised restrictions on trade or strengthen economic and social cohesion) or would otherwise significantly damage Member States' interests; and/or - action at Community level would produce clear benefits by reason of its scale or effects compared with action at the level of the Member States.'

${ }^{14}$ See Swaine (n 1) 53. Several competences in the AFSJ are for example limited in this way; Article 81(1) TFEU, 81(2) (B) TFEU; 81(3) TFEU; Article 82(2) TFEU; Article 83(1) TFEU; Article 88(1) TFEU.

${ }^{15}$ See Bermann (n 1) 370; Gráinne De Búrca, 'Re-appraising Subsidiarity’s Significance after Amsterdam' (1999) Harvard Jean Monnet Working Paper no. 7/1999, 25; Frederick J Lee, 'Global Institutional Choice' (2010) 85 New York University Law Review328, 330.

${ }^{16}$ Regarding the scope of EU legislative competence within the context of the internal market; see René Barents, 'The Internal Market Unlimited: Some Observations on the Legal Basis of Community Legislation' (1993) 30 Common Market Law Review 85, 106-109.

${ }^{17}$ See regarding scope of application of the fundamental freedoms in the field of citizenship: See Koen Lenaerts, ' 'Civis europaeus sum': from the cross-border link to the status of citizen of the Union' (2011) 3 FMW Online journal of free movement of workers 6, 6-7.

$<$ http://ec.europa.eu/social/main.jsp?catId=737\&langId=sv\&pubId=6193\&type=1\&furtherPubs=no $>$. Accessed 29 June 2014.

${ }^{18}$ It is, for example, unclear whether Article 21 TFEU, given the Court's ruling in Ruiz Zambrano (Case C343/09 Ruiz Zambrano [2011] ECR I-01177, paras 40-45), would require such a cross-border link to legislate on citizenship; see Lenaerts, 'Civis europaeus sum' (n 17) 17-18.
} 
because of various kinds of cross-border externalities or spill-overs. ${ }^{19}$ There is a "collective action' problem in this situation since costs to independent Member States' of regulating the problem is higher than the cost of common EU action. ${ }^{20}$ Even though the cross-border nature of the problem does not automatically justify EU action, it provides a strong presumption for a right for the EU to act on the matter. If there is a truly transnational problem and Member States cannot resolve that problem, the legitimacy for the Union to act in the matter does not seem to be disputed. ${ }^{21}$

Whilst the cross-border argument constitutes a legitimate justification for EU action under the subsidiarity principle, we must examine to what extent it can be used to harmonize national procedural criminal laws under Article 82(2) TFEU. Peers have argued that harmonization of national procedural criminal laws in Article 82(2) TFEU cannot be limited to matters which have a specific relationship with cross-border proceedings, like the EU's civil law powers. The Treaty drafter intentionally chose a broader wording for the criminal law power, 'crossborder' dimension in Article 82(2) TFEU, than the wording of the civil law power in Article 81(1) TFEU, 'cross-border implications'. The civil-law power has always been interpreted to mean that there has to be a genuine element of two states involved. Furthermore, the EU's specific competence in Article 82(2) TFEU would be rendered meaningless if it could only be used in cross-border proceedings since Article 82(1) TFEU already sets out a power to regulate criminal proceedings with a purely cross-border nature. Moreover, the phrase 'cross-border' dimension also governs the scope of the EU's substantive criminal law powers in Article 83(1) TFEU and it is not plausible that this power was intended to be limited to cases where the offence has factual links to more than one Member State. ${ }^{22}$

Peers' argument is convincing from a systematic and linguistic perspective. It is surely correct that the wording of Article 82(2) TFEU does not require the EU legislator to limit legislation to cross-border proceedings. This being so, there is an added dimension to the competence question which Peers has not fully explored. This is the subsidiarity principle. Although a broad competence to regulate purely national procedural rules may exist ${ }^{23}$, it appears that Article 5(3) TEU severely restricts how this competence can be exercised. I argue that subsidiarity still requires the EU legislator to show that the national procedural rules to be

\footnotetext{
${ }^{19}$ See Lee (n 15) for a general description of the application of subsidiarity to resolve collective action problems.

${ }^{20}$ See Kumm (n 1) 513-515, 519-521, for the concept of 'collective action'.

${ }^{21}$ See Bermann (n 1) 370; De Búrca, 'Re-appraising Subsidiarity’s Significance after Amsterdam' (n 15) 25.

${ }^{22}$ See Steve Peers, EU Justice and Home Affairs Law (OUP 2011) 670-671.

${ }^{23}$ See Article 5 (1) TEU: 'The limits of Union competences are governed by the principle of conferral. The use of Union competences is governed by the principles of subsidiarity and proportionality.'
} 
regulated either concern or have strong implications for cross-border judicial cooperation. ${ }^{24}$ This entails that the crucial competence question under Article 82(2) TFEU is not one of determining whether competence exists in abstracto but whether the specific EU legislative initiative is directly concerned with a cross-border situation or harmonizes national procedural rules that have clear implications for cross-border judicial cooperation. If the envisaged measure regulates issues that have a purely local dimension, the measure must be condemned regardless of whether it is done on the basis of the subsidiarity principle or on the basis of Article 82(2) TFEU. ${ }^{25}$

Peers has, however, added another pragmatic argument to defend why harmonization of national criminal procedural rules cannot be limited to cross-border criminal proceedings. Taking the example of evidence, he suggests that although rules on mutual admissibility of evidence must have a link to cross-border proceedings, it will be hard in practice to limit their impact to cross-border cases. Harmonization to ensure mutual admissibility cannot easily be restricted to cases which have a specific cross-border element since the evidence might be collected before it was clear that such an element was present. The point applies equally to the EU's powers as regards victims' and suspect's rights a fortiori because it would not be clear in the early stages of a proceeding whether there is a cross-border element or not. The suspects might all be in the country when the investigation commences, but then they might have moved at some stage in the proceedings of the investigation, at which point there is a cross-border element. This argument is clarified by a comparison to civil proceedings. Whilst it is very difficult to fix a date in criminal proceedings, the date is fixed in civil proceedings when you take the actual step of lodging the official documents before the courts. At that point, it is possible to determine whether there is a cross-border element. ${ }^{26}$

Peers' 'pragmatic' argument is supported by legislative practice from the EU institutions. The Presumption of Innocence Proposal is a case in point. In this proposal, the Commission has sustained that Article 82(2) (b) TFEU provides the legal basis for legislation applicable not only to cross-border criminal proceedings, i.e. proceedings with a link to another Member State but also to domestic cases. It argues that a precise prior categorisation of criminal proceedings as cross-border or domestic is impossible in relation to the majority of cases. It

\footnotetext{
${ }^{24}$ See Edinburgh Guidelines (n 11), 7.

${ }^{25}$ Pursuant to Article 263 (2) TFEU the Court shall have jurisdiction to hear cases 'on grounds of lack of competence' and 'infringements of the Treaties'.

${ }^{26}$ See Peers, EU Justice and Home Affairs Law (n 22) 670-671; House of Lords' European Union Committee, The European Union's Policy on Criminal Procedure, EU Sub-Committee E (Justice and Institutions), EU Criminal Procedure Policy, Steve Peers- Oral Evidence, 30th Report of Session 2010-12, 135-136.
} 
observes that all previous proposals on procedural rights of defendants followed this logic as they provided for certain minimum rights to be applicable in all criminal proceedings. ${ }^{27}$

The pragmatic argument for not limiting cooperation to cross-border cases were also endorsed in the discussions before the House of Lords' European Union Committee. It was argued that it would be impractical to limit minimum standards for criminal procedure to cross-border cases as there is no clear definition of such cases. Cases may start this way, end up being domestic only, or the converse, by which time the application of enhanced EU minimum standards will be too late. Moreover, in order to support the instruments of mutual recognition it is necessary to cover what may appear to be purely domestic cases as well as 'clear' cross-border cases where the offender or victim is a national of or resident in a Member State other than the State where the crime occurred. The offender may for example commit a crime in another Member State, and his previous convictions may be relevant to that later trial. ${ }^{28}$ It is not feasible to regulate the position of cross-border victims, without paying attention to national victims as well. This would lead to a situation where cross-border victims enjoy rights not open to nationals, which would be at odds with the freedoms relating to the EU common space. ${ }^{29}$

Admittedly, it is difficult to define 'cross-border cases'. There is, at least, two alternative ways on how to define them. The first is to have a broad definition and include as a crossborder case any case which has any transnational element, however remote or indirect it is. This would involve not only proceedings with an offender or perpetrator from another Member State but also crimes involving a victim or offender from a third country and complex crimes where the evidence is in another country than the one where the suspect and accused are citizens and proceedings which theoretically may have transnational

\footnotetext{
${ }^{27}$ See Commission, 'Commission Staff Working Document, Impact Assessment, Accompanying the document Proposal for measures on the strengthening of certain aspects of the presumption of innocence and of the right to be present at trial in criminal proceedings', Brussels, 27.11.2013, SWD (2013) 478 final, 29; See also House of Lords' European Union Committee, The European Union's Policy on Criminal Procedure, EU Sub-Committee E (Justice and Institutions), EU Criminal Procedure Policy, Bar Council of England and Wales - Written Evidence-, 30th Report of Session 2010-12, HL Paper 228, 6-7, for similar recognition of this practice. ${ }^{28}$ See House of Lords' European Union Committee, The European Union's Policy on Criminal Procedure, EU Sub-Committee E (Justice and Institutions), EU Criminal Procedure Policy, Ministry of Justice- Written Evidence, 30th Report of Session 2010-12, HL Paper 228, 81; House of Lords' European Union Committee, The European Union's Policy on Criminal Procedure, EU Sub-Committee E (Justice and Institutions), EU Criminal Procedure Policy, Justice- Written Evidence, 30th Report of Session 2010-12, HL Paper 228, 57; Bar Council of England and Wales (n 27), 6-7.

${ }^{29}$ See Marc S Groenhuijsen and Antony Pemberton, 'EU Framework Decision for Victims of Crime: Does hard law make a difference?' (2009) 17 European Journal of Crime, Criminal Law and Criminal Justice 43,44-45; Rianne Letschert and Conny Rijken, 'Rights of victims of crime: tension between an integrated approach and a limited legal basis for harmonisation' (2013) 4 New Journal of European Criminal Law 227, 228.
} 
implications. ${ }^{30}$ The second one is to have a very narrow definition, and only apply EU minimum procedural rights for defendants and victims in 'pure' cross-border scenarios, where either a victim or a suspect is involved in a trial in another State than the state in which they are citizens. Having said that, I am not sure whether any of these concepts give a proper understanding of the concept of 'cross-border' cases. I would argue for a third option, a 'middle-way' option which restrains the competence in Article 82(2) TFEU in a reasonable way without risking hampering the adoption of useful EU criminal law procedural measures. This 'middle-way' option suggests that the competence in Article 82(2) TFEU is not only limited to 'pure' cross-border cases but also covers proceedings which although having only national victims and national defendants have a strong transnational dimension. This could be the case where both the victim and the defendant are from the same Member State but where the criminal act has taken place in another Member State. ${ }^{31}$ Given the apparent transnational link in such cases, we can properly conceptualize them as 'cross-border' cases. A similarly strong transnational link could be found in cases where evidence must be mutually recognised for a trial in another Member State than where it is collected. ${ }^{32}$ Nevertheless, we still have a quite narrow definition of 'cross-border' cases. It is, for example, clear that the proposed understanding of 'cross-border cases' does not accept theoretical, indirect and abstract crossborder implications ${ }^{33}$ as justifications for the EU to act under that provision. ${ }^{34}$ In sum, the definition of cross-border proceedings involve situations where the defendant or the victim is not from the Member State where the trial is held, situations where evidence must be mutually recognised for a trial in another Member State than where it is collected and situations where the offence at issue was committed in another Member State than the one where the trial is held.

\footnotetext{
${ }^{30}$ See European Commission, 'Study on Cross Border Legal Aid Project', JLS/2008/E4/009, Final Report, 8.

${ }^{31}$ This is in tune with the current understanding of the scope of Article 81 TFEU, see House of Lords' European Union Committee 23rd Report of Session 2005-06, European Small Claims Procedure, Report with Evidence HL Paper 118, para 212.

${ }^{32}$ See, however, the House of Lords' European Union Committee, The European Union's Policy on Criminal Procedure, EU Sub-Committee E (Justice and Institutions), EU Criminal Procedure Policy- Report, 30th Report of Session 2010-12, HL Paper 228, paras 52-53, takes a very broad approach to the competence in Article 82(2) TFEU arguing that it is not practical or strictly necessary for EU criminal procedure legislation to be limited to cross-border offences.

${ }^{33}$ See however, Ministry of Justice (n 28), 81 and Peers, 'Oral Evidence' (n 26), 135-136, which seem to support that a national situation which theoretically could have a cross-border dimension, should fall within the EU's competence.

${ }^{34}$ See for this convincing point, House of Lords' European Union Committee, 1st Report of Session 2004-05, Procedural Rights in Criminal Proceedings, Report with Evidence, 7 February 2005, The Stationery Office Limited, HL Paper 28, 15-17.
} 
Although this is still a not fully developed concept I am going to sketch out some scenarios which fall under the definition. The proposed definition would mean that migrant EU workers which are victims or offenders in another Member State than their home Member State would be entitled to protection from the EU regime. This covers typical free movement cases which for example involve e.g. a lorry driver who is arrested in another Member State as a result of a traffic accident ${ }^{35}$ or Cowan situations ${ }^{36}$ where a person becomes victim in another Member State than their own. It is also clear that all discussions on mutual recognition of evidence and mutual recognition instruments such as arrest warrants and prohibition orders ${ }^{37}$ falls under the heading of cross-border cases. ${ }^{38}$

What is then the rationale behind this narrow definition? First, the subsidiarity principle suggests that EU harmonization under Article 82(2) TFEU must be limited to cross-border cases. The subsidiarity principle dictates a presumption in favour of Member State action which can be rebutted only if it is shown that the issue involves clear cross-border elements. If the problem at issue is of a local nature or only incidentally affects more than one Member State, the EU should not act on the matter. ${ }^{39}$ This is, for example, the case when it comes to regulating criminal procedures in local situations. ${ }^{40}$ Secondly, it was probably the intention of the Treaty drafters, i.e. the European Convention, that cooperation should be restricted to cross-border cases. Working Group X, which was responsible for drafting the provisions in Title V, suggested that Article 82 TFEU should only permit the adoption of common rules on criminal procedure to the extent that such rules relate to procedures with transnational

\footnotetext{
${ }^{35}$ See Commission's legal aid study (n 30) 8 for these examples.

${ }^{36}$ Case C-186/87 Cowan v Trésor public [1989] ECR 00195; Case C-164/07 Wood [2008] ECR I-4143.

${ }^{37}$ The mutual recognition instruments falls, with the exception of evidence, under the scope of Article 82(1) TFEU.

${ }^{38}$ See Walter Perron, 'Perspectives of the harmonization of criminal law and criminal procedure in the European Union’ Asbjørn Strandbakken and Erling Johannes Husabø (eds) Harmonization of Criminal Law in Europe(Intersentia 2005) 18; House of Lords' European Union Committee, The European Union's Policy on Criminal Procedure, EU Sub-Committee E (Justice and Institutions), EU Criminal Procedure Policy, Viviane Reding- Oral Evidence, 30th Report of Session 2010-12, HL Paper 228, Q 55, 122; Commission's legal aid study (n 30) 8.

${ }^{39}$ See Josephine Van Zeben, 'Regulatory Competence Allocation: The Missing Link in Theories of Federalism' (2012) Law, Institutions and Economics in Nanterre Workshop, Paris, France, 11 December 2012, 30<http://economix.fr/pdf/seminaires/lien/Van-Zeben.pdf> Accessed 29 June 2014.

${ }^{40}$ See Kimmo Nuotio 'Harmonization of Criminal Sanctions in the European Union- Criminal Law Science Fiction’ in Asbjørn Strandbakken and Erling Johannes Husabø (eds) (eds), Harmonization of Criminal Law in Europe (Intersentia 2005) 465-466, 470; Felicitas M Tadić, 'How harmonious can harmonisation be? A theoretical approach towards harmonisation of (criminal) law' in André Klip and Harmen van der Wilt (eds), Harmonisation and Harmonising Measures in Criminal Law (Royal Netherlands Academy of Science 2002)8, $14,19$.
} 
implications and are needed to ensure the full application of mutual recognition regimes. ${ }^{41}$ It even appeared that many Convention members had insisted that the exercise of EU competence should only be allowed in matters where this was justified by a cross-border dimension. Article 82(2) TFEU was specifically revised and the words 'criminal matters with a cross-border dimension' were added for this purpose. ${ }^{42}$ Thirdly, democratic reasons favour restricting common EU rights to cross-border proceedings. If one considers in which situations it is important to have special protection for victims and offenders those situations are limited to scenarios where the victim and the offender are involved in a trial in another Member State than their own. Suspects and victims in a trial involving cross-border elements have much less capacity or possibilities, because of cultural and language barriers, to defend themselves or in the case of victims, obtain recognition, protection and support. Member States are neither likely to give special protection to cross-border victims or defendants. There is, as stated by Joerges and Neyer, a strong suspicion that the legitimacy of governance of Member States is flawed as it normally remains inevitably one-sided and selfish. Due to the fact that a single states' democracy represent collective identities of the citizens of that state, they do not have proper mechanisms ensuring that foreign interests are taken into account within their decision-making processes. In such situations where the democratic process within the Member States is likely to lead to a failure to protect transnational interests such as cross-border victims or defendants, EU action is required. The objective of protecting such victims and defendants are thus better achieved at EU level. ${ }^{43}$ It is precisely the crossborder elements of domestic criminal procedure, i.e. transnational victimhood or rights for cross-border offenders, which makes the EU a more legitimate body than Member States to act on a matter. ${ }^{44}$

Having argued that subsidiarity limits the exercise of the EU's competence under Article 82(2) TFEU to regulation of cross-border proceedings, I move on to examine one of the most

\footnotetext{
${ }^{41}$ Emphasis added to underline that the idea was to limit cooperation to 'cross-border' cases. The legal basis of Article 82(2) TFEU was separated at an early stage from Article 82(1) TFEU; see European Convention, CONV 426/02, 'Final report of Working Group X "Freedom, Security and Justice"', Brussels, 2 December 2002, 11-12. ${ }^{42}$ See European Convention, CONV 727/03, 'Draft sections of Part Three with comments', Brussels, 27 May $2003,32$.

${ }^{43}$ See Christian Joerges and Jürgen Neyer, 'From Intergovernmental Bargaining to Deliberative Processes: The Constitutionalisation of Comitology', (1997) 3 European Law Journal 273, 294; Miguel Poiares Maduro, 'Reforming the Market or the State? Article 30 and the European Constitution: Economic Freedom and Political Rights', (1997) 3 European Law Journal55, 76-77; Alexander Somek, 'The Argument From Transnational Effects I: Representing Outsiders Through Freedom of Movement' (2010) 16 European Law Journal 315, 319 321, 323-24.

${ }^{44}$ See Bar Council of England and Wales (n 27), 13; Richard Lang, 'The EU's New Victims' Rights Directive: Can Minimum Harmonization Work for a Concept like vulnerability’? (2013) 22 Nottingham Law Journal 90, 94.
} 
usually employed reasons for EU action under Article 82(2) TFEU; the 'mutual recognition' justification.

\section{B) Improvement of judicial cooperation and mutual recognition}

Generally, it seems that a key rationale for efforts to harmonize domestic criminal procedures has been to improve international judicial co-operation. It has been argued that inter-governmental cooperation is seriously hampered by diverging systems of national procedural criminal law. ${ }^{45}$ Mutual recognition is a key concept in this regard and harmonization is mentioned unconditionally in Article 82(2) TFEU as a tool to facilitate the development of the mutual recognition principle. ${ }^{46}$ By reducing and approximating current differences between the various criminal procedural laws, it is envisaged that the Member States will have more trust in other legal systems and therefore be more willing to mutually recognize judicial decisions. ${ }^{47}$

Harmonization is viewed as the solution to the mutual trust problems inherent in the present EU system of judicial cooperation based on mutual recognition. ${ }^{48}$ Mutual recognition has encouraged dominance of the smallest common denominator and led to a watering down of procedural guarantees. Member States do not perceive that they can trust the adequacy of other Member States' criminal justice systems for the purposes of mutual recognition. This perception is reinforced by the fact that Member States diverge in the way they comply with the procedural safeguards of the European Convention and by the fact that European Court of Human Rights has found a significant number of violations against Member States. ${ }^{49}$ To restore the balance required for the establishment of an area of freedom, security and justice, Member States' criminal procedures must be harmonized. Harmonization of common procedural safeguard is a necessity for mutual recognition to work as well as for the building

\footnotetext{
${ }^{45}$ See Joachim Vogel 'Why is the harmonisation of penal law necessary? A comment' in André Klip and Harmen van der Wilt (eds), Harmonisation and Harmonising Measures in Criminal Law (Royal Netherlands Academy of Science 2002) 60; Anne Weyembergh, 'The Functions of Approximation of Penal Legislation Within the European Union' (2005) 12 Maastricht Journal of European and Comparative Law 149, 164.

${ }^{46}$ See Council, 'Resolution of the Council of 10 June 2011 on a Roadmap for strengthening the rights and protection of victims, in particular in criminal proceedings' [2011] OJ C 187/01; Weyembergh (n 45) 155; Valsamis Mitsilegas, EU Criminal Law (Hart 2009) 42.

${ }^{47}$ See Gert Vermeulen, 'Where do we currently stand with harmonisation in Europe?' in André Klip and Harmen van der Wilt (eds), Harmonisation and Harmonising Measures in Criminal Law (Royal Netherlands Academy of Science 2002 73; Working Group X (n 41) 11.

${ }^{48}$ See Working Group X (n 41) 8, 13; 'Draft sections of Part Three with comments' (n 42) 31.

${ }^{49}$ See SWD (2013) 478 (n 27), 10-11, 13-29; Commission, 'Commission Staff Working Document, Impact Assessment, accompanying the Proposal for a Directive of the European Parliament and of the Council on the right to information in criminal proceedings', Brussels, 20.7.2010, SEC (2010) 907, 7- 8.
} 
of mutual trust among the judicial authorities of the Member States. ${ }^{50}$ Having said this, we must recognize that this argument has its limits as otherwise the EU would have an endless mandate to make all criminal procedural laws uniform. The most important one is that the EU legislator must be able to show that harmonization of procedural criminal laws actually will lead to positive consequences for the principle of mutual recognition. ${ }^{51}$ The limits to the mutual recognition argument are further discussed in detail in section II (D).

The rationale for EU action for mutual recognition measures is, notwithstanding the limit that EU legislation must be shown to benefit mutual recognition regimes, compelling overall. International judicial cooperation involves a clear-cut cross-border dimension and addresses a situation where normally Member States alone cannot enhance such cooperation. Given this, there is a case for EU action under the subsidiarity principle for traditional mutual recognition measures such as the European Arrest Warrant and for measures that clearly supports existing mutual recognition instruments. ${ }^{52}$ Having accounted for the mutual recognition argument, we move on to consider whether the free movement argument could be used to justify harmonization of national criminal procedures.

\section{C) Enhancing free movement within the EU}

In addition to the transnational nature of the issue to be regulated ${ }^{53}$, the most common way of defending why EU action rather than Member State action on a matter is warranted is on the basis that it facilitates free movement. ${ }^{54}$ The internal market justification is a wide one for the Union to employ when justifying Union action. Potentially, any difference in the laws of the different Member States is capable of being construed as a potential distortion in the conditions of competition between states, or as a barrier to the effective functioning of the single market. When the Court defines an obstacle in the context of free movement law, it also defines the kind of things that may be harmonized. This wide interpretation of the internal market is supported by the Union legislative institutions' use of the legal basis in

\footnotetext{
${ }^{50}$ See Valsamis Mitsilegas, 'The Limits of Mutual Trust in Europe's Area of Freedom, Security and Justice: From Automatic Inter-State Cooperation to the Slow Emergence of the Individual' (2012) 31 Yearbook of European Law 319, 363-371; Fletcher, Gilmore and Lööf (n 7) 51, 127; Weyembergh (n 45) 156-157, 159.

${ }^{51}$ See Mitsilegas, 'The Limits of Mutual Trust' (n 50), 365-366.

${ }^{52}$ See Weyembergh (n 45) 165; Bar Council of England and Wales (n 27$) 13$.

${ }^{53}$ See above section II (A) for an account of this argument.

${ }^{54}$ See Article 3(3) TEU; Article 4(2) (a) TFEU; Protocol (no) 27 on the internal market and competition. This justification is explicitly enshrined as a basis for the Union action under Article 114 TFEU and Article 115 TFEU.
} 
Article 114 TFEU suggesting that there are no constraints on Union action under the internal market paradigm. ${ }^{55}$

The internal market justification has also been important to defend the approximation of EU procedural criminal law. It has been suggested that such approximation is needed to ensure the exercise of the free movement of persons within the EU. The day-to-day life of people should be facilitated, and the difficulties with which citizens are confronted in cross-border litigation should be neutralized as far as possible. Access to the procedural rules is very difficult in cross-border litigation. Whilst individuals cannot expect to know and understand 25 different laws, everybody should have easy access to the rules of the game. Differences in national procedural rules reduce access to justice and affects legal certainty. For these reasons they are obstacles to the fundamental freedoms. ${ }^{56}$

The Court's case-law on the scope of the fundamental freedoms and victim rights supports a broad interpretation of EU competence to harmonize domestic criminal procedures. The Cowan judgment is the leading ruling. This case was concerned with a British citizen, Cowan, who had, after being injured from an assault suffered by him at the exit of a metro station in Paris, applied for compensation from the French Trésor Public(Treasury) for this injury. Cowan was, however, denied compensation because he did not satisfy the conditions for obtaining the compensation as he was neither resident in France or a national of a country which had entered into a reciprocal arrangement with France. Cowan argued that the French rules on obtaining compensation were discriminatory and prevented tourists from going freely to another Member State to receive services there, thus infringing Article 18 TFEU.

The Court held that the principle of equality precludes a Member State from making the award of a right to a person in a situation governed by Union law subject to the condition that he hold a residence permit or be a national of a country which has entered into a reciprocal agreement with that Member State. The Court also found that the prohibition of discrimination was applicable since Cowan's situation was governed by the rules on the freedom to provide services which includes the freedom for the recipients of services to go to another Member State in order to receive a service there and that tourists must be regarded as

\footnotetext{
55 See De Búrca (n 15) 25-27; Gareth Davies,' Democracy and Legitimacy in the Shadow of Purposive Competence' (2013) European Law Journal, 8-9. Doi: 10.1111/eulj.12079.

${ }^{56}$ See Commission,' Proposal for a Directive of the European Parliament and of the Council establishing minimum standards on the rights, support and protection of victims of crime', Brussels, 18.5.2011, COM(2011) 275 final 2-3 ('Victims Proposal', 'Proposal); SWD (2013) 478 (n 27), 8- 9, 17-19; Weyembergh (n 45), 166167.
} 
recipients of services. The French Government, however, submitted that the right to obtain compensation, because it was a manifestation of the principle of national solidarity and assumed a closer bond between that state than a tourist receiving services, could be restricted to persons who are either nationals of that State or foreign nationals resident on the territory of that State. The Court disagreed and held that when EU law guarantees a natural person the freedom to go to another Member State, the protection of that person from harm in the Member State in question, on the same basis as that of nationals and persons residing there is a corollary of that freedom of movement. The French Government also argued that the contested rules were not subject to the prohibition of discrimination because it fell within the law of criminal procedure, which is outside the scope of the Treaty. The Court, nevertheless, held that although the rules of criminal procedure in principle are matters for which the Member States are responsible, such rules may neither discriminate against persons who exercise their free movement nor restrict the fundamental freedoms guaranteed by EU law. The Court concluded that the French rules on compensation were contrary to the prohibition of discrimination laid down in the Treaties. ${ }^{57}$ On the basis of this ruling and if we assume that there is congruence between the scope of the fundamental freedoms and the scope of the EU's harmonization competence $^{58}$, it seems that the EU legislator can also justify EU harmonization of domestic criminal procedures with reference to free movement concerns.

Limits to the justifications for harmonization of EU procedural criminal law

Even if there are, as accounted for above, several justifications for EU action to harmonize domestic criminal procedures, there are also corresponding limits to the use of these justifications. The central limit to these justifications is, as discussed above, the need to ensure that EU legislation conforms to the subsidiarity principle. However, as Article 5(3) TEU offers little guidance as to how subsidiarity will act as a check on the exercise of EU competence, we must once again turn to the Edinburgh Guidelines to ascertain in what way subsidiarity sets down limits to EU competences. These guidelines suggest that the most important limit is to ask for evidence for substantiating the rationale for EU action. This approach is supported by the third criterion in the Edinburgh guidelines which require that it is substantiated that EU action, whether based on internal market foundations, mutual recognition rationales or the transnational nature of the problem, offer 'clear benefits' in

\footnotetext{
${ }^{57}$ Case C-186/87 Cowan v Trésor public (n 36) paras 2-6, 8, 10-20.

${ }^{58}$ For this argument, see above the first part of this section.
} 
comparison to Member State action. ${ }^{59}$ This strict evidence-based approach is also supported by the fact that the EU must, pursuant to the guidelines, substantiate the need for EU action by quantitative and qualitative indicators. ${ }^{60}$ If these guidelines are considered in conjunction, it appears that the subsidiarity principle postulates a standard of proof. If the question of 'clear benefits' at the Union level is in doubt, because for example the Union has failed to substantiate the right to EU action with qualitative or quantitative indicators, that doubt must be resolved in favour of the exercise of national policy choices. This standard of proof is also supported by the Treaties which set forth that decisions should be taken 'as closely as possible to the citizen, ${ }^{, 61} 62$

If we employ this evidence-based interpretation of the guidelines and ask for 'clear benefits' in order to justify EU legislation, it becomes possible to challenge an illegitimate use of the cross-border argument, the mutual recognition justification and the internal market rationale. First of all, there are certainly situations where the cross-border argument will not be convincing. If the problem at issue is of a local nature or only incidentally affects more than one Member State, the EU should not act on the matter. ${ }^{63}$ Indirect or theoretical cross-border effects cannot, as the Court stated in the Tobacco Advertising case, be used as reasons for acting at the Union level. The cross-border effect must be of such a nature that the Member States themselves cannot effectively deal with the problem. ${ }^{64}$ There are also limits to the broad internal market argument employed for harmonization. Economic theory suggests that EU harmonization can only take place if the Union legislator show by empirical evidence that there are national divergences which give rise to a "market failure" ${ }^{, 65}$ or a concrete risk of

\footnotetext{
${ }^{59}$ See Edinburgh Guidelines (n 11) 20; De Búrca (n 15) 28-30; Bermann (n 1) 370, 379.

${ }^{60}$ See Edinburgh Guidelines (n 11) 20.

${ }^{61}$ See the preamble; Article 1(2) TEU; Article 10(3) TEU; Protocol (No 2) on the Application of the Principles of Subsidiarity and Proportionality (n 5).

${ }^{62}$ See Derrick Wyatt, 'Could a Yellow Card for National Parliaments strengthen Judicial as well as Political

Policing of Subsidiarity?' (2006) 2 Croatian Yearbook of European Law and Policy 1, 8-9, for this argument; see also in a similar vein, Swaine (n 1) 53, 55, 57-58.

${ }^{63}$ See Zeben (n 39) 30.

${ }^{64}$ See Case C- 376/98 Germany v Parliament and Council (Tobacco Advertising) [2000] ECR I-08419, paras 8384; De Búrca (n 15) 25.

65 'Market failure' can generally be defined as 'deviations from perfect markets due to some element of the functioning of the market structure'; See World Trade Organization (WTO) Secretariat,

'World Trade Report 2004- Exploring the linkage between the domestic policy environment and international trade' Chapter 3, 150-151. <http://www.wto.org/english/res_e/booksp_e/anrep_e/wtr04_2c_e.pdf>. Accessed 29 August 2014. It include for example protectionist trade barriers, distortions to competition,

regulatory costs and inefficiencies arising from multiple regimes and the externalities arising from negative effects occurring in one state as a result of an activity that is regulated or not regulated in another Member State; see Niamh Moloney, EC Securities Regulation (2nd edn, OUP 2008) 27.
} 
failure in the form of distortions to competition or obstacles to the fundamental freedoms. ${ }^{66}$ That the internal market justification must be subjected to such an evidence-based test requiring the Union to show proof of an existence or a likely risk of market failures is supported by the Court's case-law on the scope of Article 114 TFEU. Subsidiarity has, as suggested by Horsley, conditioned the Court's approach in setting the scope to EU powers under Article 114 TFEU. The classical pronouncements of the Court in Tobacco Advertising that the Union does not enjoy a general power to regulate the internal market, and that it has to show 'appreciable distortions to competition,' amounted to a strong reinforcement of the subsidiarity principle. ${ }^{67} \mathrm{~A}$ mere finding of disparities between national rules and an abstract risk of distortions of competition was not, according to the Court, sufficient to justify the choice of Article 114 TFEU as a legal basis. ${ }^{68}$

Finally, it is also possible to challenge the mutual recognition justification. Whilst calls for harmonization is often made on the ground that differences in national legislation obstructs international judicial cooperation and free movement, such claims are often not substantiated. These calls rely on a false notion of cause and effect. There may be many other possible causes for problems of mutual recognition apart from differences between national law systems. Existence of a language barrier, the shortage of resources and adequately trained personnel may be the factors behind why free movement is obstructed or mutual recognition becomes ineffective. ${ }^{69}$ Moreover, if the EU intends to harmonize for example procedural rights on the basis that such harmonization secures mutual trust and facilitates mutual recognition it must show that a specific harmonization measure of specific rights really help to improve mutual recognition. It is too vague to refer to the general idea that the arguably inadequate protection for defendants or witnesses in the Member States lead to problems of mutual trust among the Member States' judicial authorities. ${ }^{70}$ The EU legislator must identify, by empirical evidence, that the general lack in certain Member States of protection of defendants for example in terms of their right to have translation ${ }^{71}$ or defendant's right to be

\footnotetext{
${ }^{66}$ See Van Zeben (n 39) 23-24; Roger Van den Bergh, 'The subsidiarity principle in European Community law: some insights from law and economics' (1994) 1 Maastricht Journal of European and Comparative Law 337, 350-354; Simon Deakin, 'Regulatory competition and legal diversity: which model for Europe?' (2006) 12 European Law Journal 440, 453- 454.

${ }^{67}$ See Horsley (n 1) 269-270.

${ }^{68}$ See Case C- 376/98 Tobacco Advertising (n 64), paras 84, 106-107.

${ }^{69}$ See Vermeulen (n 47), 71-73; Fletcher, Gilmore and Lööf (n 7) 129.

${ }^{70}$ See Directive 2010/64/EU of the European Parliament and of the Council of 20 October 2010 on the right to interpretation and translation in criminal proceedings, [2010] OJ L 280/1, recital 3, for an example of such a vague formulation.

${ }^{71}$ ibid.
} 
present at its own trial ${ }^{72}$ is what makes judges refuse executing mutual recognition instruments. $^{73}$

To sum up, I argue that subsidiarity proposes the following substantive test to be applied when examining EU procedural criminal law legislation. First, the Union must show that there is a problem having a cross-border dimension which either give rise or risk giving rise to an obstacle against the fundamental freedoms or ineffective application of previous established EU rules. Potential obstacles does not justify Union action, unless the evidence shows that there is a concrete risk, i.e. that it is 'likely', that divergent criminal procedural criminal laws actually cause obstacles to the free movement of persons or mutual recognition regimes. ${ }^{74}$ Secondly, even if the EU legislator is able to establish the existence of such a risk or problem, it must show that Union action is significantly more efficient than Member State action in avoiding the risk or remedying the problem. ${ }^{75}$ This test would for example examine whether the EU measure, by supporting previous mutual recognition regimes, really corrects a problem of insufficient protection of victims and offenders in a cross-border situation or a problem of mutual admissibility of evidence. ${ }^{76}$

III

\section{A CONCRETE SUBSIDIARITY ASSESSMENT OF THE VICTIMS DIRECTIVE}

This section provides for, by examining the recently proposed Victims Directive, a more in-depth analysis of a piece of legislation to show the how the subsidiarity principle should be applied. The purpose of the Victims Directive is to develop mutual trust between criminal justice authorities, by ensuring that the rights of victims are fully respected, supported and protected throughout the EU and that victims have effective access to justice, appropriate information and restoration. ${ }^{77}$ The Directive sets forth several rights for victims and their

\footnotetext{
${ }^{72}$ See Commission, 'Proposal for a Directive of the European Parliament and of the Council on the strengthening of certain aspects of the presumption of innocence and of the right to be present at trial in criminal proceedings', Brussels, 27.11.2013, COM(2013) 821 final, 17, Article 8.

${ }^{73}$ See Fletcher, Gilmour and Lööf (n 7), 128-129, 202; Robin Lööf, 'Shooting from the Hip-Proposed Minimum Rights in Criminal Proceedings' 12 (2006) European Law Journal 421, 426-428.

${ }^{74}$ See Case C-376/98 Tobacco Advertising (n 64) paras 84-85, 106-107.

${ }^{75}$ See Bermann (n 1), 370, 383-384, 451; Swaine (n1) 5.

${ }^{76}$ See Article 82(2) (A) - (C) TFEU.

${ }^{77}$ See Victims Directive (n 10), Article 1(1); Commission, 'Commission Staff Working Paper, Impact Assessment, Accompanying the document; Communication from the Commission to the European Parliament, the Council, the European economic and social Committee and the Committee of the Regions; Proposal for a Directive of the European Parliament and of the Council establishing minimum standards on the rights, support and protection of victims of crime, Proposal for a Regulation of the European Parliament and of the Council on mutual recognition of protection measures in civil matters', Brussels, 18.5.2011 SEC(2011) 580 final, 21;
} 
family members encompassing for example a right to information, support ${ }^{78}$, procedural rights when participating in criminal proceedings ${ }^{79}$ and right to protection ${ }^{80}$. The rights set out in the Directive apply in cross-border as well as domestic cases. ${ }^{81}$

The purpose here is to enquire whether the Commission correctly exercised its competence in conformity with the subsidiarity principle when it adopted the Victims Directive. First, I explain and set out a test of legality to employ when examining the Victims Directive. Secondly, it is discussed whether the proposal is adequately reasoned from a subsidiarity perspective. Thirdly, it is analysed whether there is 'relevant' evidence to justify compliance with subsidiarity.

\section{Test for legality}

Above, we have generally discussed how subsidiarity limits the exercise of EU harmonization competence under Article 82(2) TFEU. Building on this, I will suggest a test to be used to control whether EU legislation adheres to the subsidiarity criterion. The suggested standard implies a test of checking firstly whether there is 'adequate' reasoning for the measure's compliance with the 'subsidiarity' criterion and secondly, whether the evidence is 'relevant' to substantiate conformity with said criterion. ${ }^{82}$ On the basis of the Court's ruling in Kadi $I I^{83}$ and Tetra Laval, ${ }^{84}$ I suggest a test where the EU legislator must first articulate, at least one justification, which in theory is sufficient as basis for sustaining compliance with the subsidiarity principle. Since the subsidiarity criterion requires both a demonstration that the regulated problem has a cross-border dimension, by either obstructing or risks hampering the fundamental freedoms or frustrating the application of existing mutual recognition regimes, and that EU provide for 'clear benefits' in avoiding or remedying these problems, the EU legislator must offer a justification for both these conditions. The reference point for whether the reasons presented are adequate is whether the justifications have been recognised by the

European Council, 'The Stockholm Programme: An Open and Secure Europe Serving and Protecting Citizens', (2010) OJ C 115/1,2.3.4., 3.1.1, 3.4.1.

${ }_{78}^{78}$ See Victims Directive (n 10), Chapter 2, Articles 3-9.

${ }^{79}$ ibid, Chapter 3, Articles 10-17.

${ }^{80}$ ibid, Chapter 4, Articles 18-24.

${ }^{81}$ ibid, Article 1 (1).

${ }^{82}$ See Case C-310/04 Spain v Council [2006] ECR I-07285, paras 122-123; Joanne Scott and Susan Sturm

'Courts as Catalysts: Rethinking the Judicial Role in New Governance' (2007) 13 Columbia Journal of European Law 565, 582.

${ }^{83}$ See Joined cases C-584/10 P, C-593/10 P and C-595/10 P Commission and others $v$ Kadi (Court of Justice, 18 July 2013).

${ }^{84}$ See Case C-12/03 P Commission v Tetra Laval [2005] ECR I-00987. 
general EU law literature and the Court's case-law. If the reasoning has no logical relationship to the material subsidiarity criterion, the reasoning is inadequate. ${ }^{85}$ One example is if the EU legislator would use an argument based on the effet utile of EU law ${ }^{86}$ to justify the necessity of harmonized procedural criminal laws under Article 82(2) TFEU. ${ }^{87}$ Effe utile arguments are often used by the Court of Justice to further integrate and provide for an expansive interpretation of EU law and the scope of EU competences. As the EU legislator can only substantiate subsidiarity compliance, according to the definition I provided, with reference either to collective action problems or with reference to the fact that the issue to be regulated has clear cross-border implications, it is beyond the point to involve arguments for further EU integration and effectiveness of EU law. ${ }^{88}$ While effectiveness of EU law may be relevant to decide on whether the EU at all, pursuant to the principle of conferral in Article 5(2) TEU, can act, it is not relevant in the assessment of whether the EU pursuant to Article 5(3) TEU, because of the nature and implications of the issue to be regulated should act instead of the Member States. ${ }^{89}$

If the proposed justifications are considered compelling, the second limb of the test considers whether the justifications are defended with 'relevant' evidence in the legislative background documents $^{90}$ to support subsidiarity compliance. ${ }^{91}$ Should the EU legislator for example use evidence concerning 'deterrence' to justify the harmonization of procedural criminal laws, it would fail to conform to the standard of 'relevant evidence'. This is because the subsidiarity criterion can only be justified on the basis of evidence showing the existence of a cross-border problem which the EU is better than Member States to address. ${ }^{92}$ This standard entails requirements in relation to both the quantity and quality of the evidence. First, in order to prove a statement, it is necessary to refer to more than one source. If, for example, the

\footnotetext{
${ }^{85}$ See Philip Kiiver, The Early Warning System for the Principle of Subsidiarity (Routledge 2012) 75, 96.

${ }^{86}$ This is Kumm's example of an irrelevant justification for EU action under the subsidiarity principle; see Kumm (n 1) 520-521.

${ }^{87}$ See SWD (2013) 478 (n 27), 30, for an 'effet utile' argument.

${ }^{88}$ See Lord Mackenzie Stuart, The European Communities and the rule of law (1977 Steven and Sons) 66-67.

${ }^{89}$ See Kiiver (n 85) 75, 96; Kumm (n1), 520.

${ }^{90}$ Such documents include explanatory memorandums, impact assessments and consultation documents, including other legislative documents deriving from the Commission, the Council and the European Parliament.

${ }^{91}$ See joined cases C-584/10 P, C-593/10 P and C-595/10 P Commission and others v Kadi (n 83), paras 118119, 124, 130; Case C-12/03 P Commission v Tetra Laval (n 84)para 39. For the application of the evidence standard, see Kadi II paras 151-162. What the Court does is to monitor whether any of the relevant reasons submitted, which in theory can support the decision in themselves, is supported by sufficient evidence (para 162). This is the same method that I am proposing to apply when testing whether EU procedural criminal legislation conforms to the subsidiarity principle.

${ }^{92}$ See Alberto Alemanno 'The Emergence of Evidence-based Judicial Reflex: A Response to Bar-Siman-Tov's Semiprocedural Review' (2013) 1 The Theory and Practice of Legislation 327, 333-335, 338; Ittai Bar-SimanTov, 'Semiprocedural Judicial Review' (2012) 6 Legisprudence 271, 280, 296.
} 
evidence for the claim that divergences in national procedural rules hinder free movement is only sustained with reference to one study or article, this would be insufficient. Secondly, the invoked evidence needs to be of a reliable nature in order to pass the test. This means that the invoked evidence need to be in the nature of statistical studies, policy studies or scientific articles which provide more serious support for an argument. Such sources could for example be statistics from courts, questionnaires to individuals and Member States identifying and outlining the problems of specific mutual recognition regimes. ${ }^{93}$ Having proposed a test of legality, the next section applies this test to the Victims Proposal.

\section{B \\ Is there adequate reasoning in the Victims Proposal to justify compliance with the subsidiarity principle?}

The Commission has proposed three separate justifications for why the Victims Directive conforms to the subsidiarity criterion.

First, there is according to the Commission significant 'transnational aspects' of victimisation which 'cannot be dealt with satisfactorily by action by Member States'. People can become a victim of a crime outside their own Member State and the needs of those victims must be respected. There is a large number of EU citizens that live, work and travel around the EU and fall victim to crime whilst abroad. In this respect, around 11.3 million EU citizens live in a foreign EU State and a large majority of EU citizens that travel abroad on holidays chose another European country. Assuming that they suffer crime at the same rate as nationals, this means that around 1.7 million citizens ( $15 \%$ of the total) living abroad fall victim to crime every year. ${ }^{94}$ The cross-border argument is on the basis of the relevant literature a compelling justification. It is well-recognised, as mentioned above ${ }^{95}$, that cross-border victims have specific needs ${ }^{96}$ that do not necessarily coincide with those of national victims. ${ }^{97}$ Due to these particularities, it is clear why the Union has a special interest in protecting cross-border victims.

\footnotetext{
${ }^{93}$ See e.g. SEC (2011) 580 (n 77), Annex 11 for such quantitative indicators. However, those quantitative indicators are ex-post after implementation of a legislative measure in the Member States. I am arguing for the need to show quantitative indicators to support EU action in the first place.

${ }^{94}$ See SEC (2011) 580 (n 77), 18.

${ }^{95}$ See above section II (A).

${ }^{96}$ Such as a need for translation and interpretation (Victims Directive (n 10), Article 5(2) and Article 7) as well as specific protection and legal support to bring proceedings and participating without physically being present at the trial; see Victims Directive, Article 3(G), Article 17.

${ }^{97}$ See Irene Wieczorek, 'A Needed Balance Between Security, Liberty and Justice. Positive Signals Arrive From the Field of Victims' Rights' (2012) 2 European Criminal Law Review 141, 147; SEC (2011) 580 (n 77 ), 63.
} 
Secondly, the Commission sustains that free movement concerns can justify harmonization of victim rights. Victims may not be subject to the same rights in their country of residence compared to their home country, or in a country where they temporarily travel or visit. This risks impeding the free movement of persons and services, which is one of the fundamental requirements for the good functioning of the internal market. ${ }^{98}$ The right to not be discriminated as a victim in another Member States is, as already mentioned ${ }^{99}$, recognised by the Court of Justices' case-law as a right falling within the scope of the fundamental freedoms. In addition to having a right to non-discriminatory treatment as regards the possibilities of obtaining state compensation ${ }^{100}$, victims or close relatives to deceased EU citizens are also entitled to equal treatment as regards victims' compensation schemes for crimes committed outside the territory of the host state. ${ }^{101}$

Thirdly, harmonization of victim rights is according to the Commission justified with reference to the mutual recognition argument. Mutual recognition can only operate effectively in a spirit of confidence, whereby judicial authorities can trust in the adequacy of the rules of each Member State and that those rules are correctly applied. Criminal justice systems should have faith in each other's standards of justice, and EU citizens should also have confidence that the same level of minimum rules will be applied should they travel or live abroad. Common minimum rules will thus lead to an increased confidence in the criminal justice systems of all Member States, which in turn should lead to more efficient judicial cooperation. ${ }^{102}$ As discussed above, this is also a rationale that is well-defended by the relevant literature. ${ }^{103}$

We also know from above that subsidiarity demands the EU legislator to explain how EU action offers 'clear benefits' in relation to Member State action. ${ }^{104}$ In response to this, the Commission argues that the above offered justifications; the free movement rationale, the cross-border nature of victimisation and the need to strengthen existing mutual recognition measures, entails that EU action offers a significant added value compared to Member State action. Furthermore, action at EU level would produce clear benefits in terms of scale of the action since it will ensure that all needs of victims are addressed. EU action to assist Member

\footnotetext{
${ }^{98}$ See SEC (2011) 580 (n 77)18; Wieczorek (n 97) 143.

${ }^{99}$ See above section II (C).

${ }^{100}$ See Case C-186/87 Cowan v Trésor public (n 36), paras 10-19.

${ }^{101}$ See Case C-164/07 Wood (n 36), paras 11-16.

${ }^{102}$ See COM (2011) 275 (n 56), 2-3, 6; Roadmap (n 46), recital 6; SEC (2011) 580 (n 77) 5, 18-20, 47.

${ }^{103}$ See above section II (B).

${ }^{104}$ See above section II (D).
} 
States through practical measures will enable economies of scale to be achieved, for instance in relation to the development of training programmes, development and dissemination of information programmes. Action at EU level would also produce 'clear benefits' in terms of effectiveness of the action. Whilst some improvements on victims' rights have occurred since the adoption of the 2001 Framework Decision ${ }^{105}$, studies show that national implementing measures have not been sufficient to properly address victims' needs. New EU action will have greater enforcement mechanisms to ensure that legislation is in fact implemented and enable the deficits of previous legislation to be rectified. ${ }^{106}$

The proposed legality test only requires that the EU legislator has suggested one justification which individually, on the basis of the Court's case-law and the literature, defends compliance with the cross-border criterion and the clear benefits criterion. Applying this test it seems, at face value, that the justifications in the Victims Proposal are legitimate to defend the need for EU action on victim rights. There are at least three rationales; the free movement aspect, the transnational nature of victimisation and the judicial cooperation argument which, pursuant to the scholarship and the Court's case-law, offers independent justifications for EU action.

Nevertheless, if we dig a bit deeper in the legislative background documents, it quickly becomes clear that the reasons stated for action do not justify the scope of the proposed action. In particular, it is not explained why the EU on the basis of the stated reasons should have a general right to regulate purely internal situations, i.e. situations where the victim is victimised in their own Member State and where the judicial proceedings take place in that Member State. ${ }^{107}$ Whilst, transnational aspects of certain types of victimisation, free movement concerns and the need to facilitate mutual recognition can justify EU legislation on rights for cross-border victims, the EU's competence under Article 82(2) TFEU is, as discussed above ${ }^{108}$, limited to cross-border cases. The Commission's proposal exceeds this limit and regulates rights of all victims, regardless of whether they are victimised abroad or in their own Member State and regardless of whether the proceedings are conducted abroad or in the Member State where the victims is a citizen. ${ }^{109}$

\footnotetext{
${ }^{105}$ See Framework Decision 2001/220/JHA of 15 March 2001 on the standing of victims in criminal proceedings [2001] OJ L 82/1.

${ }^{106}$ See SEC (2011) 580 (n 77), 20.

${ }^{107}$ See Manifesto (n 4) 444; Paul Rock, Constructing victims' rights; the Home Office, New Labour, and victims (OUP 2004) 513-514.

${ }^{108}$ See above section II (A).

${ }^{109}$ That the Victims Directive (n 10) applies to all victims is clear from Article 1 and 2.
} 
The essence of my criticism goes to the rationales for EU action; the free movement argument and the mutual recognition argument which are both based on the alleged cross-border aspects of victimisation. However, in cases where victimisation has no cross-implications, the logic for harmonization of local victim rights on the basis of free movement concerns and mutual recognition rationale fails. ${ }^{110}$ Local victim rights are simply not needed for a mutual recognition regime to work or for the functioning of the fundamental freedoms. There is no movement involved and no implications for the EU's mutual recognition regimes in domestic proceedings. Even if there were a link between the regulation of victim rights in domestic proceedings and the functioning of the internal market or even though the regulation of local victim rights were to have implications for the application of the principle of mutual recognition, the Commission has failed to account for these alleged links. ${ }^{111}$ Given this failure and the fact that it seems almost impossible to envisage any scenario where local victim rights would have any impact on the working of mutual recognition regimes or the fundamental freedoms, it appears that the reasoning fails the 'adequacy' standard set forth by the first part of the subsidiarity test. This is regrettable. It is obvious that the EU legislator could elaborate rules on victim rights and defence rights that were limited to cross-border cases. If the EU took responsibility for regulating cross-border rights, it could then be left to Member States to decide on whether these rights should be applied also to national victims and national defendants. Many Member States would of course ensure that similar rights apply also to national victims and defendants. But subsidiarity suggests that this should be a choice for Member States to make. ${ }^{112}$

C

\section{Is there relevant evidence in the Victims Proposal to justify compliance with subsidiarity?}

Whilst it is sustained that the Victims Proposal does not meet the standards of adequate reasoning, it is for the sake of the argument appropriate to also analyse the Proposal on the basis of the second part of the subsidiarity test; the evidence criterion. Since the Commission has not submitted any evidence to sustain how the absence of victim rights in domestic proceedings entails an obstacle to the fundamental freedoms, I will only focus on the evidence

\footnotetext{
${ }^{110}$ See Steve Peers, 'Oral Evidence' (n 26) Q 16140.

${ }^{111}$ See House of Lords' European Union Committee, The European Union's Policy on Criminal Procedure, EU Sub-Committee E (Justice and Institutions), EU Criminal Procedure Policy, Valsamis Mitsilegas- Supplementary Written Evidence, 30th Report of Session 2010-12, 111-112, 114.

${ }^{112}$ See House of Lords' report on Procedural Rights in Criminal Proceedings (n 34) 15-16; Bar Council of England and Wales (n 27), 7.
} 
for the Commission's mutual recognition argument. I will examine the legality on the basis of the proposed test for subsidiarity compliance, demanding that at least one of the justifications proposed is supported by sufficient and relevant evidence.

Returning to the Commission's mutual recognition rationale, this argument suggests that harmonization of victim rights in both domestic proceedings and cross-border proceedings are necessary to build mutual trust which, in turn, will lead to more efficient judicial cooperation. How then is this claim substantiated? The Commission primarily refers to evidence from the consultation procedure ${ }^{113}$ to support its reasoning. It asserts that the discussions in the consultation procedure showed that the way victims are treated is a strong indicator of the quality of justice systems in general. Working on minimum standards of victims' rights is therefore a powerful means to generally increasing faith in foreign judicial systems. ${ }^{114}$

It is well-known that the execution of the European Arrest Warrant has been hampered by a concern among judicial authorities in Member States that minimum procedural rights for the offender, as established in national constitutions, the European Convention or other international conventions, has not been adhered to by the Member States issuing the arrest warrant. ${ }^{115}$ In order to address these concerns, the Commission has suggested several proposals on defence rights; first one proposal for a general framework decision in 2004 on procedural rights, then another proposal on the right to information in 2010, and finally, a third, on the presumption of innocence in 2013. All these instruments have been justified on the basis that such defence rights are necessary for building mutual trust and securing mutual recognition to work smoothly. ${ }^{116}$

The idea that harmonization of defence rights would facilitate the implementation of the current EU mutual recognition instruments, has nevertheless, been subject to cogent criticisms from Mitsilegas. He observes that the Commission's arguments in the Framework Decision from 2004 were based on the assumption that it is not compatibility as such that will improve

\footnotetext{
${ }^{113}$ The Commission held a number of direct consultations with members of the public, as well as with nongovernmental and governmental organizations. The consultation procedure and the results from it are described in the Victims Proposal, COM (2011) 275 (n 56), 5- 6; and in the impact assessment, SEC (2011) 580 (n 77), 5175.

${ }^{114}$ See SEC (2011) 580 (n 77), 6, 19, 46.

${ }^{115}$ See Valsamis Mitsilegas, 'The Constitutional Implications of Mutual Recognition in Criminal Matters in the EU’ (2006) 43 Common Market Law Review 1277, 1289, 1291-99, 1304-1305.

${ }^{116}$ See Commission, 'Proposal for a Council Framework Decision on certain procedural rights in criminal proceedings throughout the European Union', Brussels, 28.4.2004, COM(2004) 328 final, 2-3, 5-6, 7-8; Commission 'Proposal for a Directive of the European Parliament and of the Council on the right to information in criminal proceedings', Brussels, 20.7.2010, $\operatorname{COM}(2010) 392$ final , 2-3; $\operatorname{COM}(2013) 821$ (n 72) 2-3, 29.
} 
judicial co-operation but the mutual trust it creates that will enhance such cooperation. This train of thought is, nevertheless, not convincing according to Mitsilegas. As approximation must first create mutual trust, and only then in the second stage facilitates judicial cooperation, it is too indirect to work as a ground for harmonization. It is also very difficult to show that procedural minimum guarantees for defendants benefits the workings of mutual recognition regimes. The concept of "mutual trust" is also too vague to be subject to judicial review. This would, however, run counter to the Court's settled case law, according to which the choice of legal basis for a measure may not depend simply on an institution's conviction as to the objective pursued, but must be based on objective factors which are amenable to judicial review. ${ }^{117}$

Are Mitsilegas' concerns voiced against harmonization of defence rights also relevant in the field of victim rights? I argue that it is not only transposable to this field but that his criticism is even more powerful when examining the case for EU action on victim rights. The key problem of the mutual recognition argument is its evidential basis. It is insufficient to demonstrate the need for EU action by showing that mutual trust may be affected by divergences. ${ }^{118}$ Instead, there must be concrete evidence to support that divergences in the protection of victims' rights has already had negative consequences for the building of mutual trust among Member States' judicial authorities. ${ }^{119}$ The Commission would have to show that national divergences in victim rights creates such problems of mutual trust that there would be a serious risk that Member States' judicial authorities would refuse to execute a mutual recognition instrument such as the European Arrest Warrant. Regrettably, it is, however, impossible to find any such evidence in the legislative background documents. Furthermore, whilst the Commission referred to the consultations performed before the impact assessment was adopted to sustain the link between harmonization of victim rights and mutual recognition, there is no indication in the Matrix Report or any indication in the APAV report referred to by the Commission, that the respondents in the consultations considered that harmonization of victims' rights would be necessary to facilitate mutual recognition. ${ }^{120}$ Given the fact that the Commission has not presented sufficient evidence to sustain that harmonization of victim rights is needed to enhance the application of the principle of mutual

\footnotetext{
${ }^{117}$ See Mitsilegas, 'Constitutional Implications of Mutual Recognition' (n 115) 1305-1307; Case C-300/89 Commission v Council [1991] ECR I-02867, para 10.

${ }^{118}$ See SEC (2011) 580 (n 77), 17-19.

${ }^{119}$ See Case C-376/98 Tobacco Advertising (n 64), paras 84-85, 106-107.

${ }^{120}$ See SEC (2011) 580 (n 77), 48-71.
} 
recognition, it seems that the Proposal does not pass the test of 'relevant evidence' and, by consequence, infringes the subsidiarity principle on such grounds too.

\section{CONCLUSIONS AND REFLECTIONS}

This article set out to consider what limits subsidiarity imposes on the EU legislator when it proposed EU procedural criminal law legislation. It considered two themes in more detail. First, it considered the legitimate rationales for EU harmonization of domestic criminal procedures. I suggested a narrow understanding of subsidiarity by sustaining that subsidiarity dictates a presumption in favour of Member State action in the field of procedural criminal law. This presumption can only be rebutted if the legal conditions for harmonization are fulfilled. First, the Union must show that there is a problem having a cross-border dimension which either gives rise to a market failure or leads to ineffective application of previous established EU procedural criminal legislation. Secondly, the EU legislator would then have to show that the envisaged EU action gives or is likely to give significant benefit in addressing the market failure or the problem of a non-effective mutual recognition regime. It was argued that the EU's competence for regulation of national procedural rules should be limited to cross-border cases; i.e. where the defendant or the victim's suspect is not a citizen in the Member State he/she is tried; in cases where the crime is committed abroad; in cases where evidence must be mutually recognised for a trial in another Member State than where it is collected. The EU only has a legitimate interest in regulating the situations in cross-border cases. On the basis of this conceptualisation of subsidiarity, a general criticism was put forward against such EU procedural criminal law proposals in the field of defence rights and victim rights that cover both domestic and cross-border proceedings.

The second theme of the article concerned the application of the subsidiarity criterion in the field of EU procedural criminal law. I developed a two-part test for legality on the basis of the Court's ruling in Kadi II and Tetra Laval to substantiate compliance with the subsidiarity principle. First, the EU legislator must articulate at least one justification, which in theory, on the basis of the EU law literature and on the basis of the Court's case-law, is sufficient as a basis for defending compliance with the subsidiarity principle. The second limb of the test then considered whether these justifications are supported by 'relevant' evidence. This standard demands the evidence to be of a certain quantity and quality. To support, for example, the cross-border nature or free movement aspect of harmonization of national 
procedural rules, there must be references in the legislative background documents to at least two different sources. In order to be reliable and adequate, the submitted evidence must be in the form of statistical studies, policy studies and/or scientific articles. On the basis of this test, I examined the legality of the Victims Directive. It was proposed that the Victims Proposal failed to offer 'adequate reasoning' and 'relevant evidence' to conform to the subsidiarity test. First, the Commission failed to offer any legitimate explanation as to why it was necessary also to cover rights of victims in domestic proceedings. Secondly, the Commission did not substantiate how and why harmonization of victim rights would facilitate the application of the principle mutual recognition. Due to this, the Proposal was condemned as not conforming to the subsidiarity criterion.

The general discussion of the cross-border, free movement and mutual recognition $\operatorname{argument}^{121}$ and the examination of the Victims Directive, ${ }^{122}$ cautiously suggest that EU harmonization of national domestic criminal procedures has not been driven by free movement concerns ${ }^{123}$ or cross-border problems of judicial cooperation. If that is the case, what, then, is the reasons behind EU action?

I argue that the over-arching rationale for EU action on harmonization of domestic procedures is concern for creating a common European sense of justice. The added value of EU action is that only the EU can ensure that a non-discriminatory minimum level of rights are provided to suspects or victims of crime across the EU, irrespective of their nationality or country of residence. ${ }^{124}$ Formal justice ${ }^{125}$ and equal treatment of victims and offenders throughout the EU has been the central argument for the EU when claiming a right to harmonize in the field of procedural rights. ${ }^{126}$ Approximation is argued to be essential in order to reduce the inequality between European justiciables by ensuring that the standards on victims' rights and defence rights are at the same minimum level throughout the EU. It is manifestly unjust to apply

\footnotetext{
${ }^{121}$ See above section II.

${ }^{122}$ See above section III.

${ }^{123}$ See Lang (n 44) 95.

${ }^{124}$ See SEC (2011) 580 (n 77), 19-20, 46; SEC (2010) 907 (n 49), 16.

${ }^{125}$ I would like to distinguish this to substantive justice which is a separate matter. As suggested by Rawls, formal justice is that 'similar cases are treated similarly, the relevant similarities and differences being those identified by the existing norms. The correct rule as defined by institutions is regularly adhered to and properly interpreted by the authorities. This impartial and consistent administration of laws and institutions, whatever their substantive principles, we may call formal justice'... The precept of formal justice forces judges 'to justify the distinctions that they make between persons by reference to the relevant legal rules and principles' ... See John Rawls, Theory of Justice (revised edn, Belknap Press of Harvard University Press, 1999) 50-51, 208-209.

${ }^{126}$ See Vermeulen ( $\mathrm{n} 47$ ), 75 . As discussed by Elholm, this rationale has also been used for harmonization of criminal penalties, see Thomas Elholm, 'Does EU Criminal Cooperation Necessarily Mean Increased Repression?’ (2009) 17 European Journal of Crime, Criminal Law and Criminal Justice 191, 223-224.
} 
different procedural criminal laws to similar cases so that one set of rights apply in one state and another set of rights in another state. ${ }^{127}$ Limiting the applicability of EU criminal procedure measures to cross-border cases would only be detrimental to the achievement of legal certainty and equality before the law and could lead to reverse discrimination. ${ }^{128}$ A lack of EU-level minimum standards on victims' rights puts the quality of justice in the EU at a lower level than standards identified in international instruments and through case law from the European Court of Human Rights. In a common Area of Freedom, Security and Justice, this cannot be accepted. ${ }^{129}$ That justice is a major concern for the EU institutions when contemplating harmonization is witnessed by statements by high EU officials. Commissioner Reding has stated that if you have minimum rules for the suspect in the course of the proceeding, you also need to have minimum rules for the victim in the course of the proceeding. That is the balance you must have in all justice systems between the perpetrator and the victim of the crime. ${ }^{130}$ Director General Le Bail stated in a similar vein that the Victim's Directive will make sure that victims will receive the same minimum rights whether they are at home or abroad in another Member State. ${ }^{131}$

The remaining question is obviously whether the EU is competent to harmonize national procedural criminal laws on the sole basis that it promotes justice in the EU. ${ }^{132}$ The scope of EU competence crucially depends on what we consider as legitimate justifications for EU action. Should we accept the 'autonomous' justifications for harmonization, and especially its role in establishing a European common sense of justice? This implies a wide scope for harmonization. If we nevertheless only recognize 'auxiliary' justifications to foster judicial cooperation or the internal market as acceptable rationales for harmonization, there will be a

\footnotetext{
${ }^{127}$ See Tom Vander Beken, 'Freedom, security and justice in the European Union. A plea for alternative views on harmonisation' in André Klip and Harmen van der Wilt (eds), Harmonisation and Harmonising Measures in Criminal Law (Royal Netherlands Academy of Science 2002) 95-96; Council, 'Action Plan of the Council and the Commission on how to best implement the provisions of the Treaty of Amsterdam on an Area of Freedom, Security and Justice' Text adopted by the Justice and Home Affairs Council of 3 December 1998, [1999] OJ C 19/01, point 15, 18, 19;Weyembergh (n 45), 165-167.

${ }^{128}$ See Mitsilegas, 'Supplementary Written Evidence' (n 111) 113-114.

${ }^{129}$ See SEC (2011) 580 (n 77), 6, 18-20, 46.

${ }^{130}$ See Viviane Reding, (n 38), Q 60, 124. Equality and justice were also emphasised by other respondents that provided evidence to the House of Lords' European Union Committee; see Bar Council of England and Wales(n 27) 16-17; Justice (n 28), 57

${ }^{131}$ Speech by Françoise Le Bail Director-General DG Justice, 'Strengthening victims' rights in Europe', Victim Support Europe conference 'Putting victims ' rights into practice - How to implement the EU directive on victims' rights across the EU, European Parliament, Brussels, 26 November 2012, 2.

${ }^{132}$ See Elholm (n 126) 226.
} 
much tighter scope for harmonization. ${ }^{133}$ Whilst the first one might have a broader political appeal, the EU is, in my opinion, only entitled to support the second rationale.

If the demands of subsidiarity are not to be empty words we need to limit the justifications for EU action. There is no apparent reason why the EU should be entitled to strike the balance between the necessities of law enforcement and procedural safeguards and the balance between victim rights and defence rights. Member States disagree considerably on what is a fair level of procedural minimum rights for defendants and victims and do so for valid cultural and moral reasons. Whilst formal justice is often a legitimate justification for common standards, it is much more difficult to defend such harmonization with reference to substantive justice argument unless we have a common conception of what this entails. There are many different opinions on what is just, on what is advisable, and what is suitable. A Member State can for example argue that divergent protection in procedural protection for offenders should lead to a strengthening of those rights by filling in those gaps in States with none, or weak protection. Some Member States may on the other hand perceive that strengthening an offender's rights will impair the effectiveness of the criminal justice system and reduce the chances of clearing up crimes. ${ }^{134}$

The subsidiarity principle precludes the EU legislator from substituting the fairness and justice of policy choices made by Member States. ${ }^{135}$ Justice cannot, in itself, justify EU harmonization of national procedural criminal laws under Article 82(2) TFEU. The EU can only adopt measures in the field of EU procedural criminal law that cover a cross-border situation by, for example, supporting mutual recognition measures or promoting fundamental freedoms. This approach accepts reverse discrimination. Unless there is a cross-border situation, victims or suspects would have to accept the rules to which they are bound as nationals. This means that they will be treated differently depending on whether they are involved in a cross-border situation or not. ${ }^{136}$ But this is, and always has always, the central way of delimiting EU competences in regulating the affairs of the Member States.

The alternative approach of accepting a common sense of justice as a way of limiting exercise of EU competences would open the floodgates to EU harmonization. It would also fly in the

\footnotetext{
${ }^{133}$ See Weyembergh (n 45) 172.

${ }^{134}$ See Van Den Beken (n 127), 95-96; Vogel (n 45) 60-61

135 See Kumm (n1), 519-520.

${ }^{136}$ See Geert Corstens Speech 'On mutual trust and mutual recognition', tijdens het EU-seminar, Criminal justice in the post-Lisbon era, Amsterdam, 9 December 2010. <http://www.rechtspraak.nl/Organisatie/Hoge-

Raad/OverDeHogeRaad/publicaties/Pages/Criminaljusticeinthepost-Lisbonera.aspx>. Accessed 28 August 2014.
} 
face of the idea that decisions must be taken "as closely as possible to the citizens", enshrined in the preamble to the Treaties and Article 1(1) TEU. As recognised by Lang, once the EU claims to have a competence to provide for generally applicable rights, there are no longer any limits to EU competence. He notes that other EU initiatives providing for common minimum rights, such as the Charter of Fundamental Rights, contains limits to the applicability of the rights by declaring that they are only enforceable as against Member States 'only when they are implementing Union law'. There is, however, no such caveat in the Victims Directive which means that the EU common minimum rights will apply and be enforced in cases which do not contain any EU element whatsoever. A crime victim in Member State A, subjected to a crime in Member State A, committed by an offender in Member State A, can invoke the EU right before their national court without the need to establish a movement by any party to Member State A and without the need for the offence to be related in any way to the EU. ${ }^{137}$

If the EU were to have a competence to generally promote more justice in the Member States it would equally have a competence to decide on taxation and social benefits in the Member States, as those policies are inherently concerned with questions of equality and distributive justice. It is evident that neither individuals nor Member States would wish to confer such a competence on the EU. Whilst one of the objectives of the EU is to create a common area of justice $^{138}$, the means for doing so are well-defined. Such an area of justice can be created with regard only to the combat and repression of crimes and by judicial cooperation through mutual recognition. ${ }^{139}$ Harmonization of national procedural criminal law must be strictly linked to those general objectives and can only pertain to cross-border proceedings. This is how the Treaties and the subsidiarity principle have delineated EU competence in the field of procedural criminal law. If we wish for a broader harmonization competence to not only cover cross-border proceedings and measures supplementing mutual recognition, there must be a Treaty revision. The subsidiarity principle must either be loosened up or removed. I doubt, however, that the Member States would be ready to take this step at the moment. It is, therefore, with great regret, because I think for moral reasons that victims and defendants should have equal rights throughout the EU, that I must conclude that the Victims Directive

\footnotetext{
${ }^{137}$ See Lang (n 44), 95.

${ }^{138}$ See Article 3(2) TEU; Article 67(1) TFEU.

${ }^{139}$ See Article 67(3) TFEU.
} 
and other EU initiatives such as the Directive on the Right to Information ${ }^{140}$ or the Proposal on the Presumption of Innocence ${ }^{141}$, as they stand at present, would not be compatible with the precepts of the Treaties.

\footnotetext{
'This article is based on a presentation' The principle of subsidiarity and the harmonization of national criminal procedure' held on 12 June 2014 in Stockholm at a conference titled A Manifesto for European Criminal Procedure Law, organized by the European Criminal Policy Initiative. The author would like to thank the organizers of this conference, in particular Professor Petter Asp and Professor Maria-Kaiafa Gbandi and the anonymous reviewer for his/her valuable comments and patient support in the drafting process.
}

\footnotetext{
${ }^{140}$ See Directive 2012/13/EU of the European Parliament and of the Council of 22 May 2012 on the right to information in criminal proceedings [2012] OJ L 142/1.

${ }^{141}$ See $\mathrm{n} 72$ for full reference to this proposal.
} 